\title{
Una visita a don Guillermo Valencia
}

De estudiante, en la universidad, llegué a conocer al maestro Valencia a través de las páginas de una antología escolar. Recuerdo claramente la impresión confusa, pero fuerte, que produjo en mi alma la lectura apenas comprendida de "Los camellos" y "Ciguieñas blancas". Se me iba formando una imagen mental de este mágico - un viejo austero y frío que viviría sin duda envuelto en su orgullo de poeta raro, inaccesible y lejano.

El verano pasado, cuando iba proyectando una peregrinación a Colombia, me preguntaba : ¿Vale la pena pretender visitar a Guillermo Valencia? Como todos los hombres famosos, estará aburrido de saludar àl hilo interminable de aduladores, tendrá una fórmula seca para todos. Sin embargo, acompañado de mi antiguo maestro, el doctor Alfredo Coester, decidí ir a Popayán, como quien cumple un voto religioso.

Popayán es un sueño irreal, fantástico: alto, aislado, frío, se conserva majestuoso en el silencio de sus blancos caserones. En las calles, grandes carteles anuncian, con acento medieval, el examen público de algún candidato doctoral. Reunidos en la plazuela, esperando la llegada de los músicos municipales, los payaneses cuchichean entre sí, recogidos y solemnes, como si se tratara de una ceremonia religiosa. Las iglesias guardan con 
orgullo y sigilo sus esplendores barrocos, custodias de oro y esmeraldas, vestimentas fabulosas. Boquiabierto y pensativo, volvía de un paseo de vagabundo por la ciudad encantada. iY allí estaba esperándonos en nuestro hotel! ¡Don Guillermo, el maestro Valencia, el poeta delicado y refinado, estaba sentado tranquilamente en aquel monstruo de mal gusto que pasaba por hotel! ¡Adiós ilusiones! Nada de frialdad ni pompa de poeta renombrado. Nos salüdó cordial e ingenuamente. A.pesar de sus sesenta y siete años; parecía casi joven; conserva el cabello negro y sedoso y en los ojos todavía brilla la chispa altiva de su juventud. Todo su ser es sereno, equilibrado, sin afectación alguna.

$Y$ en su lenguaje se realizó el sueño de perfección que yo acariciaba al imaginar una visita a la Colombia arcaica. Me figuraba estar hablando con un hidalgo antiguo. Cuando plática, su charla es una música de sonidos clarọs y elegantes tocada con un ritmo acompasado y lento.

Nos citó para las cinco y media de aquella tarde y luego nos llevó en su coche a su quinta, "Belalcázar"; ésta dista cosa de cinco kilómetros de la ciudad. Está situada a orillas del río Cauca, en el mismo lugar donde el conquistador Belalcázar construyó su casa de campo; en efecto, la quinta de Valencia está edificada sobre parte del cimiento original. I Es de dos pisos y tiene anchos corredores en los cuatro lados, al estilo antiguo colonial de Colombia. Lo rodean grupos de eucaliptos, jazmines olorosos y bellísimas bugambilias. Los jardines, aunque descuidados, son amenos e invitan al paseo y la meditación. De los árboles y del río llega un murnullo continuo, vago, monótono.

En el piso bajo tiene don Guillermo instalada "su biblioteca, una colección enorme de tesoros en todas las lenguas y sobre todos los asuntos. Es una historia muda del desarrollo intelectual de su dueño: ediciones medievales de autores españoles, autógrafos de los poetas franceses y de Oscar Wilde, abundantes 
libros de historia y de ciencia. Todo se hallaba algo desordenat do, lo que le daba un aspecto de poeta genial.

Nos llevó arriba, a una sala de recibo llena de antigüedades históricas y objetos artísticos, un verdadero museo. Allí se nos ofrecieron copas de vino añejo y nos presentó Valencia a sus dos hijas, Luz y Josefina, que son sumamente simpáticas e inteligentes. La mayor se ha encargado de dirigir una revista de alto valor cultural, "Catleya", que merece ser más conocịda entre los aficionados americanos de la literatura amena.

Animado por la grata informalidad del grupo, me atreví a mencionar tímidamente a León de Greiff y pregunté a Valencia si la obra del poeta joven tiene algún parentesco con su propia poesía. Respondió don Guillerimo con una negativa muy redonda, y se lanzó a criticar acaloradamente la teoría de Greiff acerca de la posibilidad de escribir poesía con la técnica de la música. Según el maestro, son cosas distintas; la poesía tiene que preocuparse en parte con el significado de las palabras, la música no. El resultado de confundir la técnica de la música con la de la poesía es el de producir poesía sin sentido o música cargada de interpretaciones pictóricas extrañas a la esencia de la música. En la opinión de Valencia, es tontería decir que tal o cual pieza sinfónica describe una escena o una acción específica que sean las mismas para todos los oyentes. También tachó de prosaica la obra de Greiff. Resumió en una frase feliz la diferencia entre prosa y poesía: la poesía es bailar - andar ritmicamente; la prosa no es más que andar.

Luego salimos a ver la, puesta del sol, un cuadro fantástico de nubes ardientes y montañas que se destacaban contra las llamas. En aquel momento me dí cuenta de lo que significaba el discutido "rey degollado" de que habla Valencia en su himno "A Popayán".

Después de una merienda sencilla, servida en un ambiente 
de tranquilidad horaciana, charlamos unas horas más y volvimos a Popayán, yo con la cabeza rebosante de emociones.

\author{
JoHN T. REID, \\ Universidad de Stanford, \\ California.
}

